\title{
PENDAMPINGAN INDUSTRI KECIL MENENGAH DALAM PEMANFAATAN ASET DIGITAL UNTUK MENINGKATKAN USAHA DI MASA PANDEMI COVID-19
}

\author{
(Accompaniment Of Small Medium Industry In The Utilization Of Digital Assets To \\ Increase Business During The Covid-19 Pandemic)
}

\author{
Ariyan Zubaidi ${ }^{[1]}$, Andy Hidayat Jatmika ${ }^{[1]}$, Wirarama Wedashwara ${ }^{[1]}$, Ahmad Zafrullah Mardiansyah ${ }^{[1]}$, \\ Noor Alamsyah ${ }^{[1]}$ \\ ${ }^{[1]}$ Dept Informatics Engineering, University of Mataram \\ J1. Majapahit 62, Mataram, Lombok NTB, INDONESIA \\ Email: zubaidi13@unram.ac.id, [andy,wirarama,zaf, nooralamsyah]@unram.ac.id
}

\begin{abstract}
Abstrak
Pandemi Covid-19 memberikan dampak yang sangat signifikan terhadap dunia usaha. Dibatasinya pergerakan masyarakat membuat penurunan jumlah konsumen dan merubah frekuensi belanja masyarakat. Hal ini berdampak pada menurunnya pendapatan yang didapatkan oleh pengusaha bahkan juga banyak usaha yang tutup karena tidak adanya pemasukan. Dunia usaha diharapkan dapat melakukan terobosan-terobosan yang sesuai dengan perkembangan sekarang dengan melihat tren-tren yang ada sehingga mereka dapat beradaptasi dengan kondisi sekarang dan kembali mendapatkan pemasukan untuk kelangsungan usahanya. Perkembangan industri yang mengarah kepada industri 4.0 dimana komputer berperan penting di hampir semua aspek kehidupan, membawa kepada perlunya pengenalan dunia digital kepada industri kecil menengah. Salah satu terobosan yang banyak dilakukan oleh usaha kecil menengah adalah dengan melakukan go digital. Berbagai teknologi digital dapat diadopsi dan digunakan oleh usaha untuk dapat memperluas jangkauan pasar dan konsumen. Berbagai usaha telah berhasil bertahan di tengah masa pendemi ini dengan menggunakan teknologi digital untuk menunjang usahanya. Tujuan dari kegiatan pengabdian kepada masyarakat ini adalah mengedukasi dan mendampingi mitra untuk dapat membuat dan mengelola berbagai aset digital seperti Google My Business, Whatsapp For Business dan Instagram For Business..
\end{abstract}

Keywords: Industri Kecil Menengah, Go Digital, Google My Business, Whatsapp for Business, Instagram for Business

\section{Pendahuluan}

Pandemi Covid-19 memberikan dampak yang sangat signifikan terhadap dunia usaha. Dibatasinya pergerakan masyarakat membuat penurunan jumlah konsumen dan merubah frekuensi belanja masyarakat. Hal ini berdampak pada menurunnya pendapatan yang didapatkan oleh pengusaha bahkan banyak usaha yang tutup karena tidak adanya pemasukan. Dunia usaha diharapkan dapat melakukan terobosan-terobosan yang sesuai dengan perkembangan sekarang dengan melihat tren-tren yang ada sehingga mereka dapat beradaptasi dengan kondisi sekarang dan kembali mendapatkan pemasukan untuk kelangsungan usahanya.

Perkembangan industri yang mengarah kepada industri 4.0 dimana komputer berperan penting di hampir semua aspek kehidupan, membawa kepada perlunya pengenalan teknologi kepada Industri Kecil Menengah (IKM). Salah satu terobosan yang banyak dilakukan oleh usaha kecil menengah adalah dengan melakukan go digital. Berbagai teknologi digital dapat diadopsi dan digunakan oleh usaha untuk dapat memperluas jangkauan pasar dan konsumen. Ini dapat dilakukan dengan promosi dengan memanfaatkan berbagai teknologi digital. Metode pemasaran yang sebelumnya bersifat tradisional dan konvensional, kini telah terintegrasi dalam dunia digital [1]. Salah satu cara pemulihan usaha yaitu dengan digitalisasi usaha mikro kecil dan menengah [2]. Berbagai usaha telah berhasil bertahan di tengah masa pendemi ini dengan menggunakan teknologi digital untuk menunjang usahanya.

Program atau kegiatan yang memberikan pelatihan kepada IKM juga dilakukan pada masa pandemi Covid-19 tetapi dilakukan secara online. Hal ini dirasa kurang efektif oleh pelaku IKM karena tidak banyak pelaku IKM yang menguasai penggunaan teknologi sehingga sangat membutuhkan pendampingan langsung secara tatap muka. Dengan tatap muka, proses pelatihan dapat dilakukan langkah demi langkah dengan detail dan kesulitan yang dialami mitra dapat langsung diutarakan untuk kemudian bisa diulangi langkah-langkah yang belum jelas tersebut. 
Tujuan dari kegiatan pengabdian kepada masyarakat ini adalah mengedukasi dan mendampingi mitra untuk dapat membuat dan mengelola berbagai aset digital yang dapat dibuat secara gratis seperti Google My Business, Whatsapp Business dan Instagram for Business. Dengan adanya aset digital ini, diharapkan mitra dapat memperluas jangkauan usahanya dan lebih dikenal oleh calon konsumen melalui dunia digital. Dari kegiatan diharapkan output berupa akun di beberapa media digital yang dimiliki oleh mitra serta pengetahuan untuk penggunaanya. Untuk Google My Business sendiri, manfaat yang didapatkan dengan memiliki akunnya yaitu usaha akan terindeks pada mesin pencari Google yang dilengkapi dengan lokasi usaha dan mendapat review tentang bisnis dari pelanggan[3]. Sedangkan Whatsapp Business memberikan manfaat seperti mempermudah komunikasi dengan pelanggan, meningkatkan visibilitas bisnis, dan meningkatkan efisiensi[4]. Adapun Instagram for Business memiliki manfaat seperti promosi menjadi lebih mudah, memiliki fitur wawasan untuk mengawasi statistik pengguna, jangkauan lebih luas, adanya informasi kategori bisnis, dan dapat menganalisis target pasar [5].

\section{TINJAUAN PUSTAKA}

Penggunaan media digital untuk meningkatkan usaha bagi IKM merupakan suatu keharusan. Dengan meningkatnya pengguna internet di Indonesia yang mencapai 76.8 persen [6] dan pengguna ponsel pintar yang mencapai 167 juta orang atau 89\% dari penduduk Indonesia [7], maka semakin meningkat pula potensi jangkauan informasi mengenai usaha yang digeluti bisa disebarkan. Usaha dapat diperluas pangsa pasarnya tidak hanya di dalam provinsi saja tetapi dapat menjangkau seluruh Indonesia bahkan dunia. Hal ini didukung pula dengan munculnya model-model bisnis elektronik yang dapat dimanfaatkan [8]. Kecenderungan perubahan perilaku masyarakat Indonesia yang semakin beralih ke transaksi digital harus direspon oleh IKM supaya dapat tetap eksis dan mengembangkan bisnisnya [9].

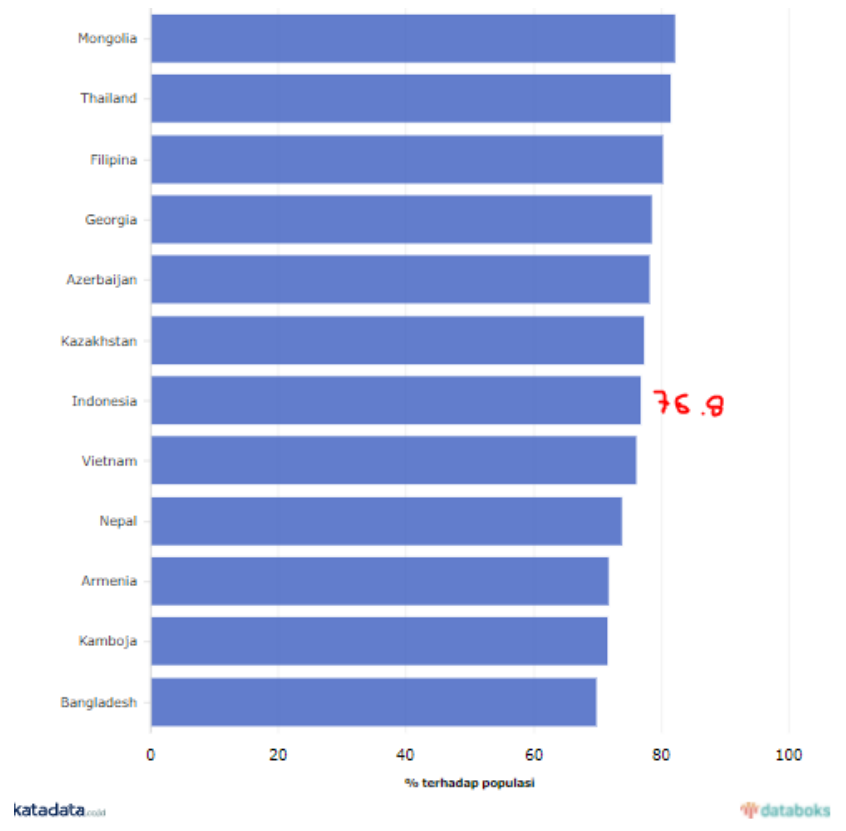

Gambar 1. Penetrasi Internet Indonesia 2021 [6].

Peningkatan penggunaan internet dan ponsel pintar ini tentu saja dapat dimanfaatkan dan menjadi peluang usaha yang lebih besar dengan menjalankan pemasaran melalui internet yang akan menjadi sumber pendapatan, selain itu promosi yang awalnya dilakukan secara offline dapat ditambahkan dengan promosi secara online, karena penggunaan internet merupakan salah satu media yang efektif untuk membangun brand dan membuat bisnis lebih banyak dikenal orang [10].

Beberapa artikel membahas mengenai pemanfaatan media digital untuk meningkatkan usaha, seperti pada [11] yang memberikan penyuluhan pentingnya penggunaan media sosial untuk meningkatkan promosi pariwisata di Lombok Barat. Masyarakat yang telah banyak mengenal media sosial belum memaksimalkan penggunaan media sosial tersebut untuk melakukan promosi pariwisata sehingga perlu diarahkan untuk menggunakannya. Pada artikel [12], dilakukan pelatihan pembuatan dan penggunaan media digital e-commerce untuk memperluas jangkauan penjualan, meningkatkan jumlah konsumen dan pada akhirnya meningkatkan jumlah penjualan. 
Pada artikel [10], dilakukan penelitian mengenai urgensi penggunaan e-marketing untuk keberlangsungan usaha UMKM di Kota Pekalongan. Hasil dari penelitian menunjukkan bahwa implementasi e-marketing melalui marketplace memberikan dampak positif di tengah pandemi Covid-19 pada ketahanan ekonomi UMKM di Kota Pekalongan. Hal ini juga dipertegas oleh penelitian yang dilakukan [8], dimana didapatkan hasil bahwa terdapat hubungan positif dan signifikan antara penggunaan media digital terhadap tingkat penjualan. Semakin tinggi penggunaan media digital maka semakin tinggi tingkat penjualan.

\section{Metode Pengabdian masyarakat}

Metode pelaksanaan kegiatan atau langkah-langkah yang akan dilakukan dalam kegiatan pengabdian kepada masyarakat ini diperlihatkan pada gambar 2. Langkah-langkah yang dilakukan adalah study literature, survei, identifikasi masalah, pembagian tugas dan penyusunan materi, implementasi kegiatan, dan penyusunan dokumentasi atau laporan kegiatan.

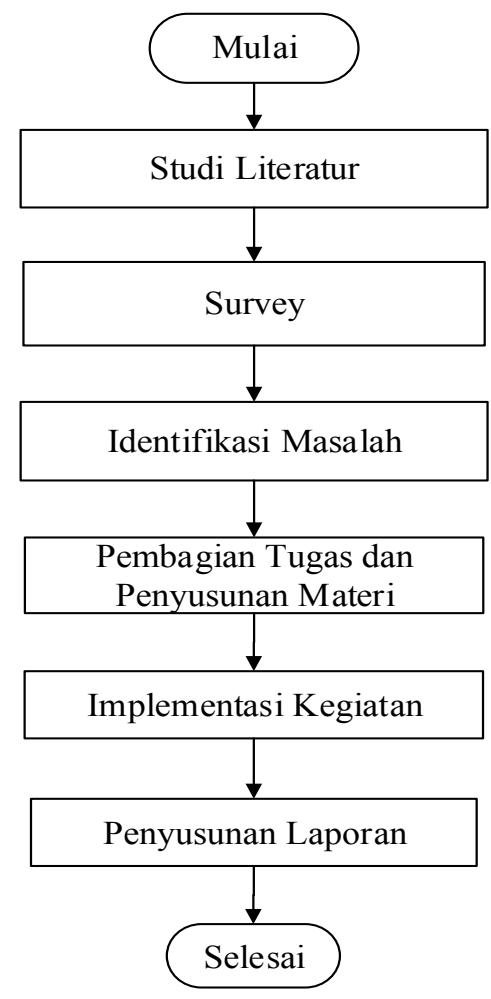

Gambar 2. Diagram alir pelaksanaan kegiatan

a. Studi Literatur

Pada tahap ini, dilakukan studi literatur terkait dengan kegiatan yang akan dilakukan. Berbagai artikel baik pengabdian dan penelitian telah membahas mengenai pentingnya penggunaan media digital untuk meningkatkan bisnis.

b. Survei

Sebelum melaksanakan kegiatan ini, dilakukan survei ke beberapa pelaku IKM yang akan dijadikan lokasi pelaksanaan kegiatan. Dari survei didapatkan kesimpulan bahwa pengetahuan terhadap aset digital masih rendah, sehingga perlu dilakukan pendampingan secara intensif.

c. Identifikasi Masalah

Tim pengabdian mengidentifikasi permasalahan dan solusi yang dapat diberikan dalam bentuk kegiatan yang akan dilakukan.

d. Pembagian Tugas dan Penyusunan Materi

Untuk dapat melaksanakan kegiatan ini, tim terlebih dahulu berkoordinasi untuk menentukan waktu pelaksanaan kegiatan, pembagian tugas dan peran masing-masing anggota serta penyusunan materi yang akan diajarkan ke pihak mitra.

e. Implementasi Kegiatan 
Pendekatan yang dilakukan yaitu dengan melakukan pendampingan secara intensif dalam beberapa pertemuan. Adapun tahapan kegiatan yang dilakukan adalah sebagai berikut :

1. Pertemuan pertama, dilakukan penyampaian materi pentingnya go digital dan menggali informasi terkait dengan asset digital yang dimiliki.

2. Pertemuan kedua, dilakukan penyampaian materi mengenai Google My Business (GMB) dan mengajarkan pembuatan dan melengkapi informasi yang ada di akun Google My Business.

3. Pertemuan ketiga, dilakukan penyampaian materi mengenai Whatsapp Business dan Instagram Business dan mengajarkan pembuatan akun dan melengkapi informasi di kedua media tersebut.

4. Pertemuan keempat, dilakukan evaluasi penggunaan media digital yang telah dibuat pada pertemuan-pertemuan sebelumnya.

5. Pendampingan secara online melalui media Whatsapp.

\section{Hasil dan Pembahasan}

Pelaksanaan kegiatan ini dilakukan dengan mengunjungi mitra ke lokasi usahanya dan memberikan edukasi dan pendampingan pembuatan aset digital yang dapat dimanfaatkan untuk melakukan promosi usaha yang dilakukan dan juga melakukan branding melalui media internet. Adapun hasil kegiatan yang telah dilakukan yaitu:

1. Pertemuan pertama.

Pada pertemuan pertama ini, dilakukan edukasi mengenai pentingnya go digital beserta cara-cara yang dapat dilakukan untuk go digital. Selain itu, dilakukan pengumpulan informasi terkait dengan aset digital yang dimiliki oleh mitra. Dari hasil observasi, mitra sudah memiliki akun di Google My Business serta Page di laman Facebook, tetapi belum dikelola dengan baik. Informasi yang dicantumkan masih seadanya dan tidak digunakan untuk mempromosikan usahanya. Selain itu, mitra belum memiliki akun Whatsapp Business dan Instagram Business. Pelaksanaan kegiatan dapat dilihat pada gambar 3.

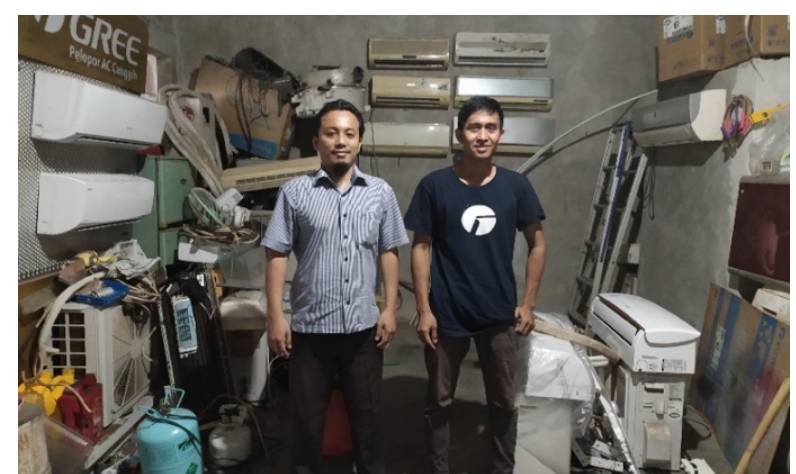

2. Pertemuan kedua

Gambar 3. Pelaksanaan kegiatan pertemuan pertama.

Pada pertemuan kedua ini, materi yang disampaikan adalah Google My Business beserta manfaat yang diperoleh jika memiliki akunnya. Dari pertemuan pertama didapatkan bahwa mitra sudah memiliki akun GMB tetapi masih seadanya sehingga dilakukan pendampingan update informasi di GMB sehingga dapat lebih mudah terindeks di Google. Pelaksanaan dan hasil kegiatan dapat dilihat pada gambar 4-5.

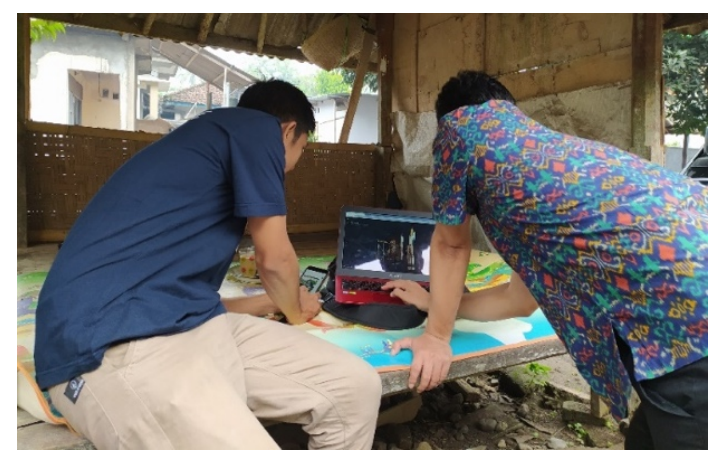

Gambar 4. Pelaksanaan kegiatan pertemuan kedua. 


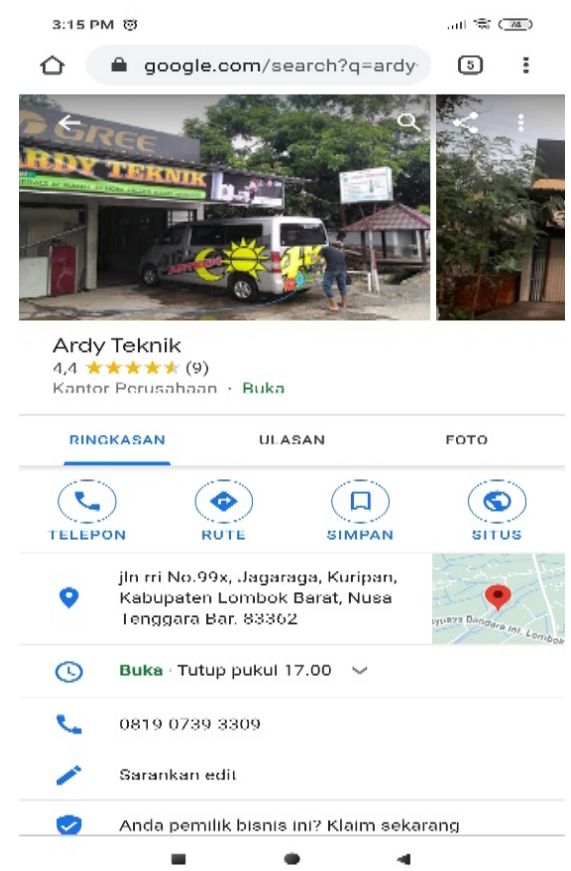

3. Pertemuan ketiga

Gambar 5. Hasil update laman GMB.

Pada pertemuan ketiga, dilakukan penyampaian materi mengenai Whatsapp for Business dan Instagram Business dan manfaat yang didapatkan dengan mempunyai akun di media-media tersebut. Kemudian, dilanjutkan dengan pembuatan akun di media-media tersebut serta melengkapi berbagai informasi yang perlu dicantumkan supaya dapat diakses oleh calon konsumen. Pelaksanaan kegiatan dan hasil kegiatan dapat dilihat pada gambar 6-8.

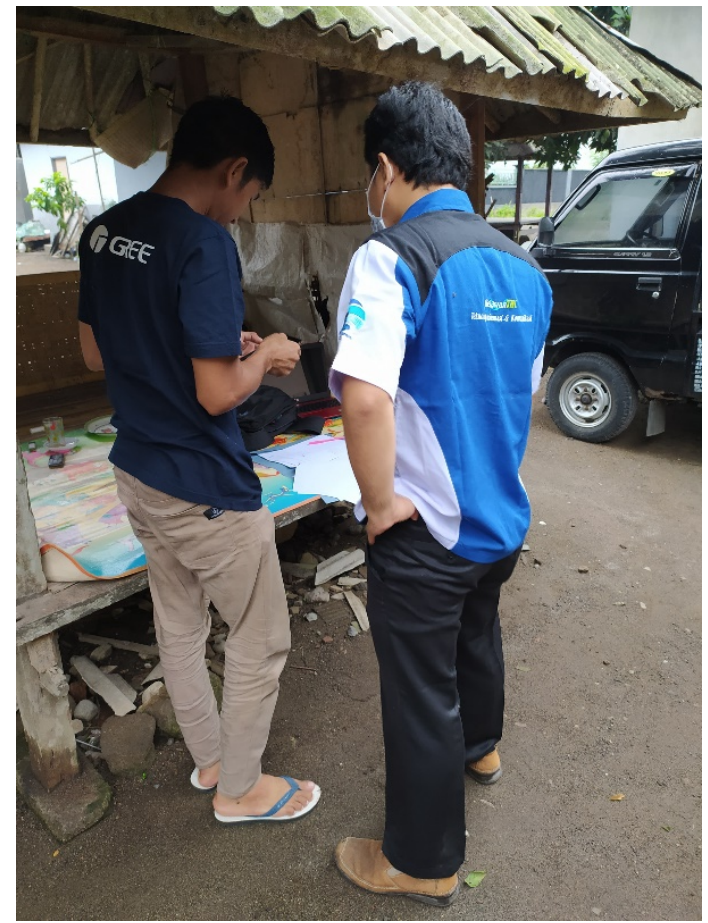

Gambar 6. Pelaksanaan kegiatan pertemuan ketiga. 

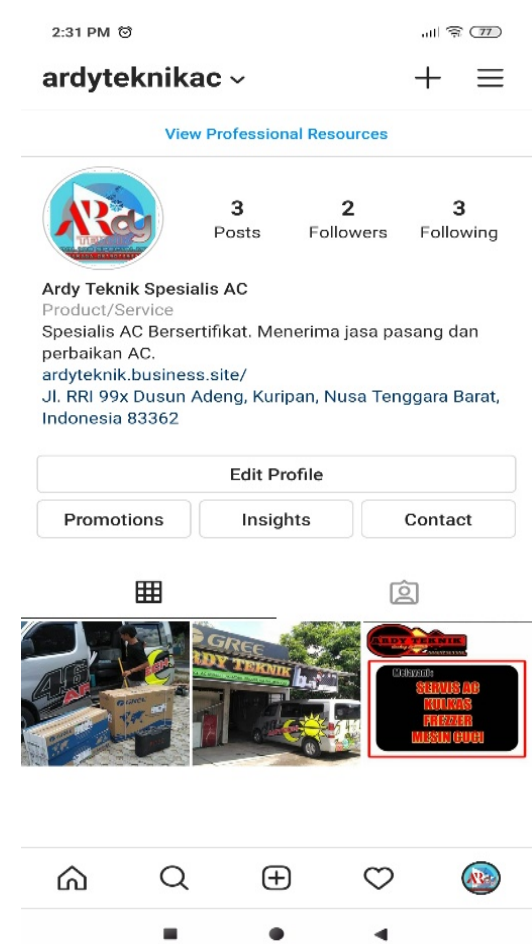

Gambar 7. Akun Whatsapp for Business dan Instagram Business mitra.

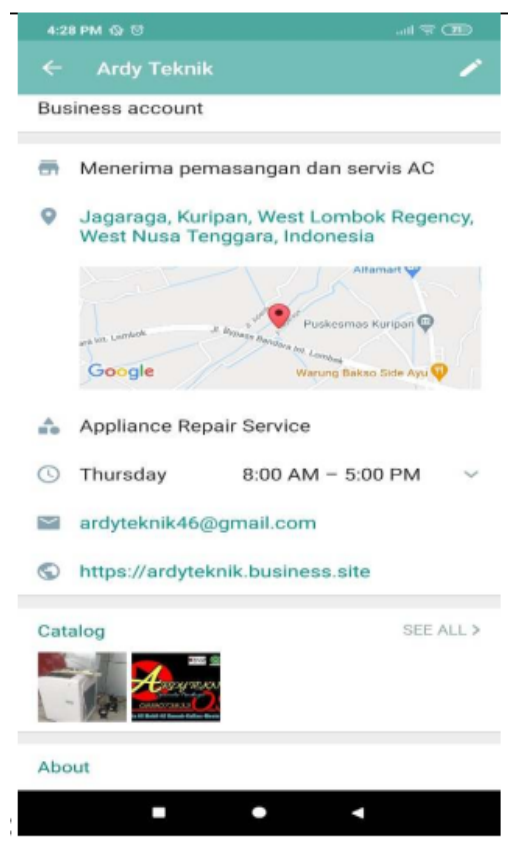

4. Pertemuan keempat

Gambar 8. Akun Whatsapp Business yang dibuat.

Pada pertemuan keempat, dilakukan evaluasi penggunaan aset digital oleh mitra dan memberikan arahanarahan terkait dengan penggunaan yang masih belum terlalu dipahami oleh mitra. Antusiasme mitra terlihat dengan adanya pertanyaan-pertanyaan kaitannya dengan penggunaan aset digital yang sudah dibuat oleh mitra. Pelaksanaan kegiatan dapat dilihat pada gambar 9. 


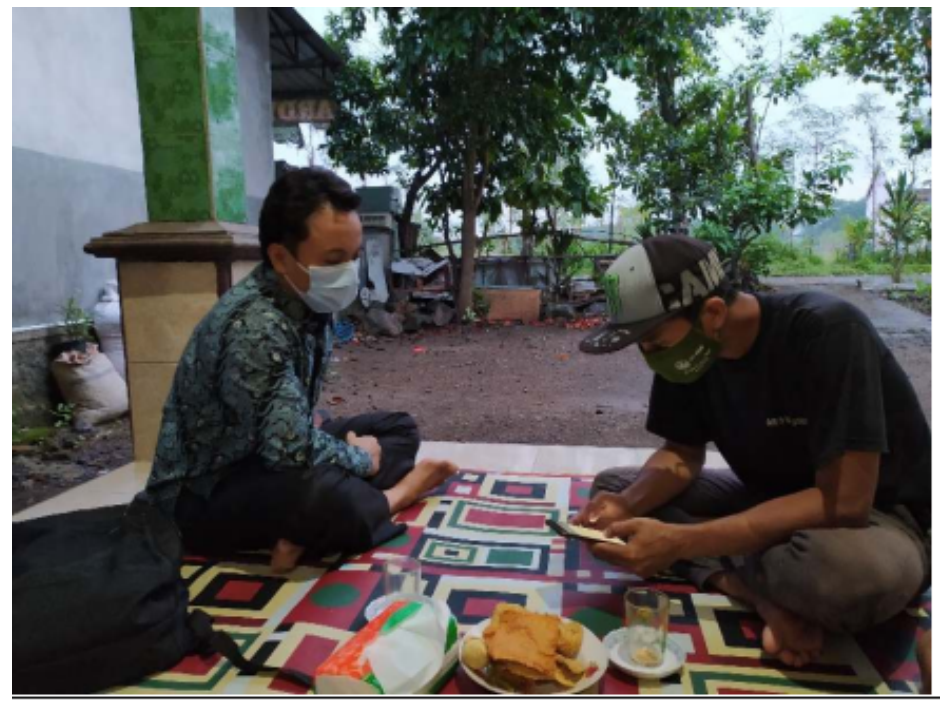

Gambar 9. Pelaksanaan kegiatan pertemuan keempat.

5. Pembimbingan secara online.

Setelah pertemuan langsung dilakukan, berikutnya dilakukan pembimbingan secara online kepada mitra melalui media Whatsapp. Mitra dapat menanyakan hal-hal yang dianggap kurang jelas melalui Whatsapp yang dapat dilakukan sewaktu-waktu.

\section{KESIMPULAN DAN SARAN}

Dari kegiatan yang sudah dilakukan, dapat ditarik kesimpulan, yaitu :

1. Mitra kegiatan yaitu pelaku IKM sangat tertarik dengan materi yang disampaikan dan praktik pembuatan aset digital. Hal ini ditunjukkan dengan keluangan waktu yang disediakan oleh mitra dalam beberapa pertemuan yang dilakukan dan juga interaksi melalui pembimbingan online.

2. Setelah kegiatan, mitra memanfaatkan akun-akun yang telah dibuat dari kegiatan ini untuk melakukan promosi dan mengisi konten-konten yang dapat mengenalkan usaha mereka ke masyarakat.

\section{UCAPAN TERIMA KASIH}

Ucapan terima kasih kami haturkan sebesar-besarnya kepada pihak-pihak yang telah mendukung kegiatan ini sehingga dapat terlaksana dengan baik, yaitu Kaprodi Teknik Informatika, Sekprodi Teknik Informatika, mitra kegiatan serta semua pihak yang tidak bisa kami sebutkan satu per satu.

\section{DAFTAR PUSTAKa}

[1] A. M. Afrilia, "Digital Marketing Sebagai Strategi Komunikasi Pemasaran 'Waroenk Ora Umum' Dalam Meningkatkan Jumlah Konsumen,” J. Ris. Komun., vol. 1, no. 1, pp. 147-157, 2018, doi: 10.24329/jurkom.v1i1.21.

[2] V. Lidyana, "Dikepung Pandemi, UMKM wajib go digital buat bertahan hidup.," detikcom, 2020. https://finance.detik.com/berita-ekonomi-bisnis/d-5251100/dikepung-pandemi-umkm-wajib-go-digital-buatbertahan-hidup (accessed Feb. 10, 2021).

[3] Jane Sucitra, "Manfaat Google My Business Untuk Promosi lokasi Usaha Anda," nextdigital, 2018. https://nextdigital.co.id/manfaat-google-my-business-untuk-promosi-lokasi-usaha-anda/ (accessed Jun. 05, 2021).

[4] I. Ismail, "Whatsapp Bisnis: Fitur, Manfaat, dan Cara Membuatnya dengan Mudah Untuk Bisnis Anda," accurate, 2021. https://accurate.id/bisnis-ukm/whatsapp-bisnis/ (accessed Jun. 05, 2021).

[5] Nur Rani D, "6 Keuntungan Menggunakan Akun Bisnis Instagram untuk Toko Online,” moota, 2020. https://moota.co/keuntungan-akun-bisnis-instagram/ (accessed Jun. 05, 2021).

[6] V. B. Iskandar, "Penetrasi Internet Indonesia Urutan ke-15 di Asia pada 2021," databoks, 2021. https://databoks.katadata.co.id/datapublish/2021/07/12/penetrasi-internet-indonesia-urutan-ke-15-di-asia-pada2021 (accessed Aug. 10, 2021). 
[7] Z. Hanum, "Kemenkominfo: 89\% Penduduk Indonesia Gunakan Smartphone," mediaindonesia, 2021. .

[8] Q. Ayuni, H. Cangara, and A. Arianto, "The Influence of Digital Media Use on Sales Level of Culinary Package Product Among Female Entrepreneur," J. Penelit. Komun. Dan Opini Publik, vol. 23, no. 2, 2019, doi: 10.33299/jpkop.23.2.2382.

[9] N. Jamiat and C. Supyansuri, "Pemanfaatan Digital Marketing Pada Umkm Sukapura Dayeuhkolot Kabupaten Bandung," Atrabis, vol. 6, no. 1, pp. 21-41, 2020.

[10] H. Awali, "Urgensi Pemanfaatan E-Marketing Pada Keberlangsungan Umkm Di Kota Pekalongan Di Tengah Dampak Covid-19," Balanc. J. Ekon. dan Bisnis Islam, vol. 2, no. 1, pp. 1-14, 2020, doi: 10.35905/balanca.v2i1.1342.

[11] G. S. Nugraha, I. G. P. S. Wijaya, F. Bimantoro, A. Y. Husodo, and A. Aranta, "Penyuluhan Penggunaan Sosial Media Untuk Kepariwisataan Desa Batulayar, Kabupaten Lombok Barat, NTB,” J. Begawe Teknol. Inf., vol. 2, no. 1, pp. 70-77, 2021, doi: https://doi.org/10.29303/jbegati.v2i1.338.

[12] A. Dwijayanti and P. Pramesti, "Pemanfaatan Strategi Pemasaran Digital menggunakan E-Commerce dalam mempertahankan Bisnis UMKM Pempek4Beradek di masa Pandemi Covid-19," Ikra-Ith Abdimas, vol. 4, no. 2, pp. 68-73, 2020, [Online]. Available: https://journals.upi-yai.ac.id/index.php/IKRAITHABDIMAS/article/download/982/772. 